\title{
Pengaruh Substitusi Biskuit MP-ASI Kemenkes dan Isolat Protein terhadap Daya Terima Snack Bar untuk Batita Usia 12-36 Bulan
}

\section{Effect of Subtitution to MP-ASI Kemenkes Biscuit and Protein Isolates towards the Acceptance of Snack Bar for Toddler (12 -36 months)}

\author{
Susi Hidayah*1 ${ }^{1}$ Dea Dellyana Wahyutia Ady ${ }^{1}$, Himatul Muhimah ${ }^{1}$
}

\begin{abstract}
ABSTRAK
Latar Belakang: Batita (Bayi dibawah usia Tiga Tahun) adalah anak yang berusia antara $12-36$ bulan. Pada tahap ini, pertumbuhan anak berjalan lebih lambat jika dibandingkan pada usia $0-12$ bulan. Asupan energi dan zat gizi yang cukup penting untuk mencapai potensi pertumbuhan dan perkembangan yang optimal. Masalah gizi kurang pada batita akan mengganggu perkembangan kognitif dan proses eksplorasi lingkungan yang merupakan karakteristik anak pada usia ini.

Tujuan: Penelitian ini bertujuan untuk mengetahui daya terima dan kandungan protein snack bar yang disubstitusi dengan biskuit MP-ASI Kemenkes dan isolat protein.

Metode: Desain yang digunakan dalam melakukan penelitian ini adalah eksperimental murni dengan menggunakan metode Rancangan Acak Lengkap (RAL) yang terdiri atas 1 formula kontrol biskuit MPASI Kemenkes, 1 formula kontrol snack bar, dan 1 formula perlakuan. Uji daya terima dilakukan kepada 3 panelis terlatih dan 25 panelis tidak terlatih. Satu formula terbaik dari hasil uji organoleptik akan diuji kandungan protein dengan metode Kjeldahl. Uji statistik menggunakan uji Anova Friedman Test $(\alpha=0,05)$.

Hasil: Hasil uji daya terima menunjukkan formula terbaik adalah formula perlakuan dengan subtitusi biskuit MP-ASI Kemenkes $24 \%$ dan isolat protein $16 \%$ (f2). Hasil analisis statistik menunjukkan adanya perbedaan signifikan antara biskuit, formula kontrol, dan formula terbaik pada aspek tesktur $(p=0,000)$, warna $(p=0,003)$, dan rasa $(p=0,046)$. Dalam 100 gram formula terbaik mengandung $6,68 \mathrm{~g}$ protein dan dapat memenuhi $10 \%$ kecukupan protein jika mengonsumsi sebanyak 4 keping snack bar.
\end{abstract}

Kesimpulan: Substitusi $24 \%$ biskuit MP-ASI Kemenkes dan $16 \%$ isolat protein meningkatkan daya terima

snack bar untuk batita usia 12-36 bulan.

Kata kunci: batita, gizi kurang, snack bar, MP-ASI

\section{ABSTRACT}

Background: Toddler (Infant under Three Years Old) are child between the ages of 12 and 36 month. In this stage, the growth velocity of children slower than in ages of $0-12$ month. Adequate energy and nutrients important to achieve optimal growth and development. Undernutrition problem in toddlers will impairs cognitive development and environment explores process that constitute child's characteristic in this ages.

Objectives: This study aims to determine the acceptance and the proteins content of snack bars substituted with MP-ASI biscuit and the isolates protein.

Methods: The design used in this study was experimental using a completely randomized design method. There are 3 formulas used, a control formula of MP-ASI biscuits from Kemenkes, a control formula of snack bar, and a treatment formula. The acceptance test was conducted on 3 trained panelists and 25 untrained panelists. The best formula from the organoleptic test results were tested for protein content using the Kjeldahl method. The statistical test was Anova Friedman Test $(\alpha=0.05)$. 
Results:The results of organoleptic test showed that the best formula was the treatment formula with $24 \%$ of MP-ASI biscuits substitution and $16 \%$ isolates protein ( 22$)$. The statistic analysis showed that there were significant differences on the aspects of texture $(p=0.000)$, color $(p=0.003)$, and taste $(p=0.046)$. In 100 grams of best formula contains 6,68 grams of protein and can fulfill $33.4 \%$ of the daily protein adequacy of children aged 1-3 years

Conclusion: Substitution of 24\% MP-ASI biscuits and $16 \%$ Isolates protein increase the acceptance of snack barfor toddler (12-36 months)

Keywords: toddler, undernutrition, snack bar, complementary food

\author{
* Koresponden: \\ susi.hidayah-2015@fkm.unair.ac.id \\ Susi Hidayah \\ ${ }^{1}$ Departemen Gizi, Fakultas Kesehatan Masyarakat, Universitas Airlangga, Kampus C Mulyorejo, 60115, \\ Surabaya, Jawa Timur, Indonesia
}

\title{
PENDAHULUAN
}

Bayi dibawah usia tiga tahun (Batita) adalah anak yang berada pada rentang usia antara 12 - 36 bulan. Pada usia ini pertumbuhan anak berjalan lebih lambat jika dibandingkan dengan periode sebelumnya yaitu pada usia 0

- 12 bulan. Akan tetapi, anak pada usia ini tetap memerlukan pemenuhan zat gizi makro dan mikro yang cukup untuk mendukung pencapaian pertumbuhan dan perkembangan yang optimal(Brown, 2011). Pemenuhan energi dan zat gizi yang tidak tepat atau kurang pada usia ini akan menimbulkan masalah gizi kurang yang akan berdampak buruk pada kecerdasan dan pembentukan kualitas sumber daya manusia di masa yang akan datang(Diniyyah and Nindya, 2017). Selain itu, gizi kurang juga akan menyebabkan seorang anak mengalami gagal tumbuh dan meningkatkan angka kesakitan serta kematian pada balita(Fauziah, Rahman and Hermiyanti, 2017).

Berdasarkan data RISKESDAS (Riset Kesehatan Dasar) tahun 2013, tercatat angka gizi kurang di Indonesia pada tahun 2007 adalah sebesar 18,4\%. Pada tahun 2010 mengalami penurunan sekitar 0,5\% menjadi 17,9\% dan pada tahun 2013 terjadi peningkatan sebesar 1,7\% menjadi 19,6\%(Kementerian Kesehatan Republik Indonesia, 2013). Hal tersebut menjadi masalah serius yang harus diperhatikan dan memerlukan upaya pencegahan, salah satunya melalui pemenuhan zat gizi yang cukup dan pemberian makanan pendamping air susu ibu (MP-ASI) yang tepat. MP-ASI penting untuk mendukung pertumbuhan fisik dan perkembangan kognitif anak yang sedang berkembang pesat pada tahap usia batita(Mufida, Widyaningsih and Maligan, 2015).

Makanan pendamping air susu ibu (MP-ASI) merupakan makanan atau minuman selain dari ASI yang mengandung zat gizi yang diperlukan oleh tubuh yang berasal dari beragam jenis bahan makanan. MP-ASI sangat diperlukan untuk memenuhi kebutuhan gizi anak usia batita karena seiring dengan bertambahnya usia anak kebutuhan gizinya juga bertambah sedangkan ASI hanya mampu memenuhi setengah dari kebutuhan gizi anak usia 12 bulan. Dalam pemberian MP-ASI perlu diperhatikan beberapa hal yaitu usia pemberian MP-ASI, jenis, frekuensi, porsi, dan cara pemberian MP-ASI(Rottie, Kundre and Datesfordate, 2017).

Di era modern sekarang ini kita dapat menemukan aneka ragam varian MP-ASI dalam bentuk biskuit, bubur instan, puding, dan lain - lain. Semakin berkembangnya varian MP-ASI tersebut mendorong peneliti untuk membuat suatu formula MP-ASI untuk makanan selingan anak usia batita dalam bentuk snack bar. Snack bar merupakan makanan ringan berbentuk batang dengan komposisi berbagai bahan makanan seperti sereal, buah, dan kacang-kacangan yang dicampur dan disatukan dengan agen pengikat (binder) misalnya sirup, karamel, coklat atau yang lainnya(Sarifudin et al., 2015). Pada formulasi snack bar ini peneliti akan membuat formula snack bar dengan komposisi bahan berupa tepung susu, gula, oat, biskuit MP-ASI Kemenkes dan isolat protein.

Biskuit MP-ASI Kemenkes merupakan produk biskuit yang dikeluarkan oleh pemerintah dengan tujuan untuk memperbaiki dan meningkatkan status gizi anak usia balita. Biskuit ini mempunyai kandungan zat gizi makro maupun mikro sesuai dengan standart MP-ASI Kemenkes sehingga, cocok digunakan sebagai bahan subtitusi pada formula MP-ASI snack bar. Selain itu, ditambahkan juga isolat protein untuk menambah jumlah protein dalam snack bar. Bahan lain seperti tepung susu, gula, dan oat digunakan untuk menambah jumlah karbohidrat dan zat gizi lainnya.

Tujuan dari penelitian ini adalah untuk mengetahui daya terima dan kandungan protein snack bar 
hasil formulasi. Produk ini diharapkan dapat memberikan manfaat kepada masyarakat dalam mencegah kejadian gizi kurang dan meningkatkan asupan zat gizi untuk pertumbuhan yang optimal.

\section{METODE}

Penelitian ini menggunakan metode penelitian eksperimental murni (true experimental). Rancangan penelitian menggunakan Rancangan Acak Lengkap (RAL) yang terdiri dari variasi 3 formula. Proporsi biskuit MP-ASI dan isolat protein yang digunakan pada pembuatan snack bar dapat dilihat pada tabel 1. Penelitian dilaksanakan pada bulan Oktober dan November 2017. Pembuatan snack bar dilaksanakan di Laboratorium

Pengolahan Gizi Fakultas Kesehatan Masyarakat Universitas Airlangga Surabaya, uji organoleptik dilaksanakan dengan metode door to door di daerah Mulyorejo Surabaya, dan uji kandungan protein dengan metode Kjeldahl dilakukan di Laboratorium Gizi Departemen Gizi Kesehatan Fakultas Kesehatan Masyarakat Universitas Airlangga Surabaya.

Alat yang digunakan dalam pembuatan snack bar adalah oven, loyang, timbangan digital, sendok makan, baskom dan panci kecil. Bahan yang digunakan adalah oat, tepung susu, gula, isolat protein, dan biskuit MP-ASI Kemenkes. Oat yang digunakan dalam pembuatan snack bar adalah oat instan berwarna putih yang masih baru dan memilki aroma khas gandum, bertekstur halus, serta terbebas dari benda asing. Tepung susu yang digunakan dalam pembuatan snack bar bertekstur halus, berwarna putih kekuningan, dan memiliki aroma khas susu. Isolat protein yang digunakan adalah isolat protein dari kacang kedelai. Isolat protein kedelai ini memiliki warna yang hampir sama dengan tepung susu, tetapi memiliki tekstur yang lebih halus daripada tepung susu. Adapun alur pembuatan snack bar adalah sebagai berikut :



Gambar 1. Diagram Alir Pembuatan Snack bar

Uji tingkat kesukaan dilakukan pada 3 panelis terlatih yaitu dosen ilmu gizi dan 25 panelis tidak terlatih yaitu ibu batita. Formula yang diberikan kepada panelis terlatih dan tidak terlatih yaitu 1 formula kontrol snack bar, 1 formula perlakuan, dan 1 formula kontrol biskuit MP-ASI Kemenkes. Formula kontrol snack bar adalah formula dasar pembuatan snack bar tanpa substitusi biskuit MP-ASI Kemenkes dan isolat protein. Formula perlakukan adalah formula snack bar yang sudah disubstitusi dengan isolat protein dan biskuit MP-ASI.

Proporsi biskuit MP-ASI dan isolat protein didasarkan pada hasil - hasil percobaan yang telah dilakukan langsung oleh peneliti selama penelitian berlangsung. Penambahan biskuit kurang dari $15 \%$ dan isolat protein lebih dari $25 \%$ membuat snack bar menjadi kenyal dan tidak mudah patah, sedangkan jika proporsi biskuit lebih dari $40 \%$ dan isolat kurang dari 5\%, snack bar akan rapuh dan mudah hancur. Formula terbaik adalah formula yang mendapatkan penilaian tertinggi pada uji daya terima terhadap aspek tekstur, aroma, rasa, dan warna. Uji statistik yang digunakan pada penelitian ini adalah uji statistik Anova Friedman Test $(\alpha=0,05)$. H0 $=$ Tidak ada perbedaan warna, aroma, rasa dan tekstur antar formula $(>$ $\alpha=0,05)$. H1 = Minimal ada sepasang formula yang berbeda ( $*$ H0 ditolak jika $\leq \alpha=0,05$ ). Penelitian ini telah disetujui oleh komisi etik Fakultas Kesehatan Masyarakat Universitas Airlangga dengan No 593KEPK. 


\section{HASIL DAN PEMBAHASAN}

Hasil uji daya terima oleh panelis tidak terlatih terhadap tingkat kesukaan tekstur snack bar disajikan pada Gambar 2 yang menunjukkan bahwa dari aspek tekstur, formula perlakuan (substitusi MPASI Kemenkes $24 \%$ dan isolat protein 16\%) mendapat penilaian tertinggi (mean rank=2,28) dibandingkan formula kontrol snack bar (mean rank=1,64) dan formula kontrol biskuit MP-ASI (mean rank=2,08).

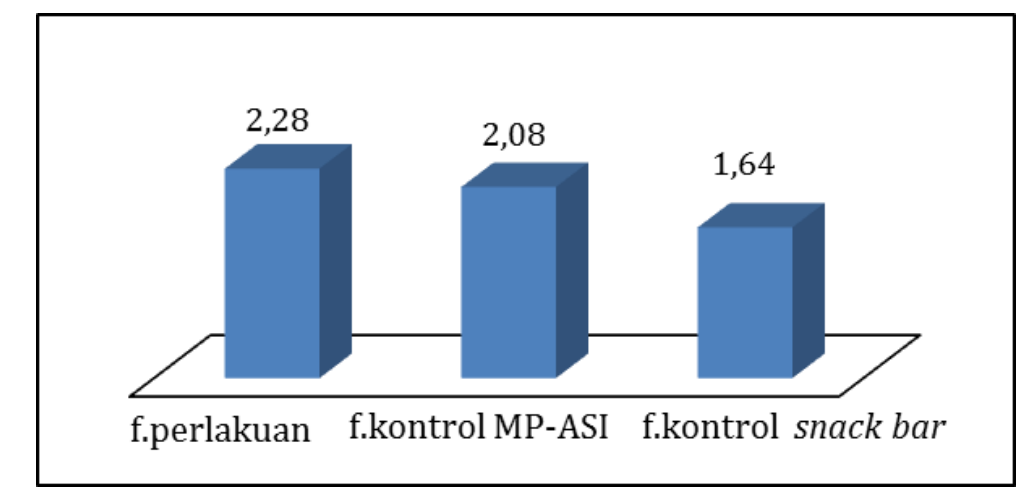

Gambar 2. Gambar Grafik Tingkat Kesukaan Tekstur

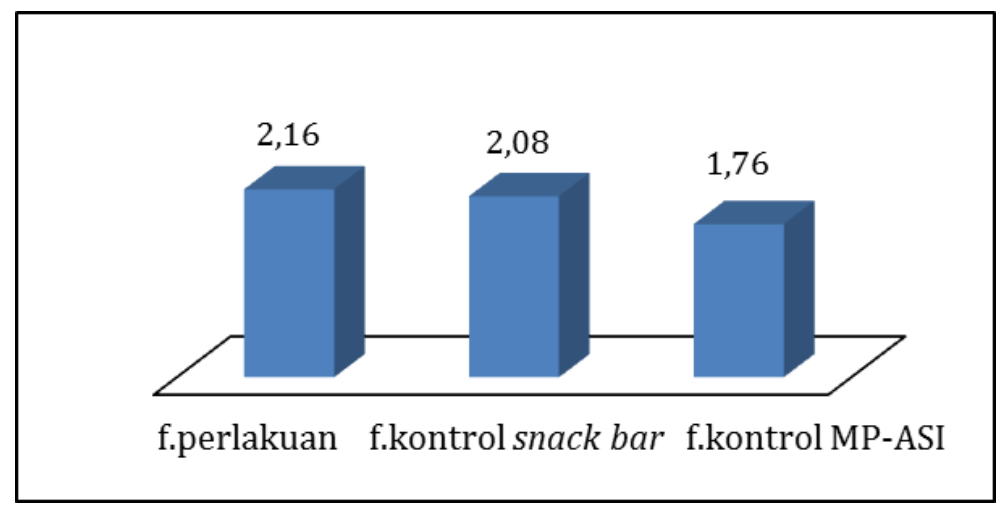

Gambar 3. Gambar Grafik Tingkat Kesukaan Aroma

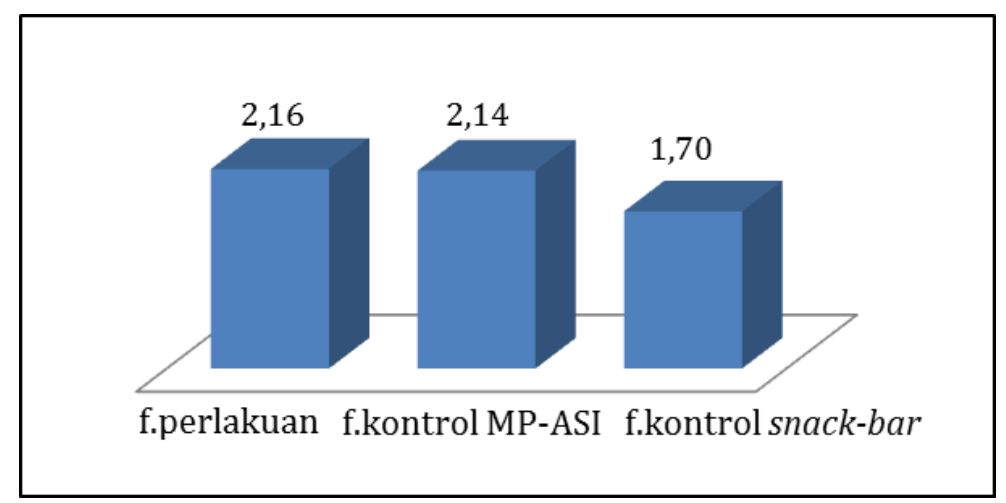

Gambar 4. Gambar Grafik Tingkat Kesukaan Rasa 


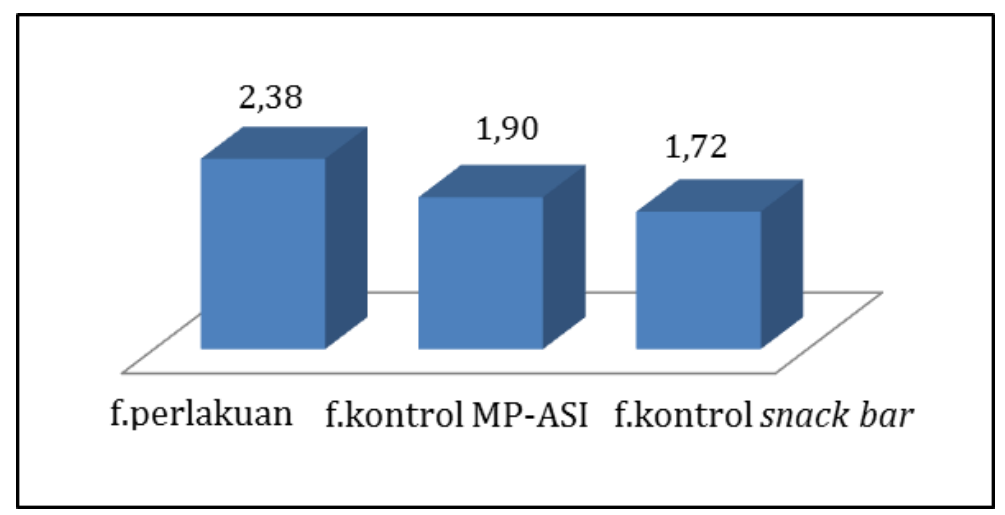

Gambar 5. Gambar Grafik Tingkat Kesukaan Warna

Tabel 1. Proporsi Biskuit MP-ASI Kemenkes dan Isolat Protein

\begin{tabular}{ccc}
\hline Formula & Biskuit MP-ASI Kemenkes & Isolat Protein \\
\hline F1 (Formula Perlakuan 1) & $12 \%$ & $8 \%$ \\
F2 (Formula Perlakuan 2) & $24 \%$ & $16 \%$ \\
F3 (Formula Perlakuan 3) & $36 \%$ & $24 \%$ \\
\hline
\end{tabular}

Tabel 2. Tabel distribusi hasil uji laboratorium kandungan gizi protein pada formula perlakuan 2 (F2) per 100 gram snack bar

\begin{tabular}{cccc}
\hline & Zat Gizi & Satuan & Hasil Uji Laboratorium \\
\hline Protein & $\mathrm{g}$ & 6,68 \\
\hline
\end{tabular}

Formula kontrol snack bar mempunyai tekstur sedikit kasar dan keras karena mengandung lebih banyak oat dibandingkan formula perlakuan. Tekstur oat yang sedikit kasar disebabkan oleh kandungan serat pangannya yang tinggi antara lain: selulosa, hemiselulosa, dan lignin(Zwer, 2010). Sedangkan, tekstur keras pada formula kontrol disebabkan karena adanya proses retrogasi amilosa pada oat yang tinggi yaitu proses terbentuknya ikatan antar amilosa yang telah terdispersi ke dalam air. Semakin banyak amilosa yang terdispersi, proses retrogasi semakin meningkat dan semakin keras pula produk yang dihasilkan(Mulyadi et al., 2014). Hal ini sejalan dengan penelitian sebelumnya yang menyatakan bahwa kandungan oat akan berpengaruh terhadap tekstur snack bar karena oat memiliki tekstur yang kasar dan kurang enak saat ditelan. Semakin banyak jumlah oat maka produk akan menjadi kering dan keras(Kurniawan, 2017).

Aroma pada snack bar yang dihasilkan tidak menimbulkan perbedaan yang signifikan antara formula kontrol dan formula perlakuan $(p=0,102)$. Pada kedua formula tersebut sama-sama memunculkan aroma dominan dari tepung susu. Aroma susu yang muncul pada produk olahan makanan disebabkan oleh adanya proses pemanasan yang kemudian menyebabkan senyawa volatil pada susu menguap dan bereaksi dengan indera penciuman(Savitri, Al-Baarri and Abduh, 2014)'(Marwah, 2018)'(Kusumastuti and Adriani, 2017). Hasil uji daya terima terhadap tingkat kesukaan aroma ditampilkan pada Gambar 3. Berdasarkan nilai mean rank diketahui bahwa panelis lebih menyukai aroma dari formula perlakuan (mean rank=2,16) dibandingkan formula kontrol snack bar (mean rank=2,08) dan formula kontrol biskuit MP-ASI (mean rank=1,76).

Rasa pada suatu produk olahan makanan merupakan gabungan dari berbagai macam rasa bahan makanan yang menyusunnya sehingga, menghasilkan rasa yang enak(Elastri, 2015). Hasil uji daya terima terhadap aspek rasa disajikan pada Gambar 4 yang menunjukkan bahwa panelis lebih menyukai aroma dari formula perlakuan (mean rank=2,16) dibandingkan formula kontrol snack bar (mean rank=1,70) dan formula kontrol biskuit MP-ASI (mean rank=2,14). Rasa yang muncul pada formula kontrol snack bar adalah perpaduan rasa khas dari oat dan susu serta rasa manis dari gula sedangkan, pada formula perlakuan rasa terbentuk dari perpaduan dari rasa manis gula, rasa khas dari susu dan oat, serta rasa biskuit MP-ASI.

Warna snack bar yang dihasilkan memiliki perbedaan yang signifikan antara formula kontrol dan formula perlakuan. Pada formula kontrol snack bar dihasilkan warna putih pucat yang muncul dari warna bahan penyusunannya yaitu tepung susu dan oat. Pada formula perlakuan muncul warna kecoklatan. Warna kecoklatan pada produk olahan makanan dapat disebabkan oleh adanya reaksi non enzimatis yang disebut dengan reaksi maillard yang terjadi selama proses pemanasan. Reaksi maillard adalah reaksi yang terjadi antara bahan yang mengandung protein dengan bahan yang mengandung gula atau karbohidrat(Sarastuti and Yuwono, 2015). Hasil uji daya terima terhadap aspek warna ditampilkan pada 
Gambar 5 yang menujukkan bahwa formula perlakuan lebih disukai dan mendapatkan penilaian tertinggi ( mean rank=2,38) sedangkan formula kontrol snack bar (mean rank=1,72) dan formula kontrol biskuit MP-ASI Kemenkes (mean rank=1,90) kurang disukai.

Hasil uji daya terima yang telah dilakukan oleh panelis selanjutnya diolah dan dianalisa untuk mengetahui perbedaan dari masing - masing formula. Hasil analisis statistik dengan uji Kruskal Wallis $(\alpha=0,05)$, menunjukkan bahwa substitusi isolat protein dan biskuit MP-ASI memberikan pengaruh yang signifikan terhadap tekstur, rasa, dan warna ( $p=0,000 ; p=0,046 ; p=0,003)$.

Indikator lain yang diuji pada penelitian ini selain daya terima adalah kandungan protein snack bar. Hasil uji laboratorium dengan metode Kjeldahl menunjukkan bahwa dalam 100 gram (10 keping) formula snack bar mengandung 6,68 gram protein. Kandungan tersebut dapat mencukupi sebesar 33,4\% angka kecukupan protein (AKP) harian anak usia 1 -3 tahun menurut AKG 2018.

Teknologi pemanasan pada proses pembuatan snack bar menyebabkan proses denaturasi protein yaitu terjadi perubahan terhadap struktur molekul protein tanpa terjadi pemecahan ikatan - ikatan kovalen(Palupi, Zakariya and Prangdimurti, 2007). Akan tetapi, disisi lain pemanasan pada proses pengolahan dapat meningkatkan daya cerna dan daya simpan protein(Sundari, Almasyhuri and Lamid, 2015). Protein sangat berguna dan berperan penting untuk mengganti sel - sel yang rusak, sebagai sumber energi, membentuk antibodi, enzim, dan hormon, serta sebagai pemelihara keseimbangan asam basa cairan tubuh(Whitney and Rolfes, 2008). Peran protein dalam mencegah gizi kurang adalah sebagai bahan pembentuk antibodi tubuh untuk mencegah infeksi berulang yang dapat menyebabkan gizi kurang pada anak.

\section{KESIMPULAN}

Substitusi biskuit MP-ASI Kemenkes dan isolat protein pada snack bar memberikan pengaruh signifikan terhadap tekstur, rasa, dan warna. Hasil uji daya terima snack bar terhadap aspek tekstur, aroma, rasa, dan warna menujukkan formula perlakuan adalah formula yang paling disukai (substitusi biskuit MPASI : Isolat Protein; 24\%:16\%). Kadar protein di dalam 10 keping snack bar dapat memenuhi 33,4\% kecukupan protein harian anak usia 1- 3 tahun berdasarkan AKG 2018 dan dapat dijadikan sebagai makanan selingan yang bisa membantu mencegah gizi kurang. Penelitian tentang snack bar ini sangat potensial untuk dilakukan penelitian lanjutan terkait kandungan zat gizi mikro yang ada di dalamnya. Selain itu, dapat pula dilakukan penelitian terkait pengaruh penambahan atau substitusi bahan lain yang mampu meningkatkan kandungan gizi MP - ASI.

\section{ACKNOWLEDGEMENT}

Terima kasih penulis berikan kepada seluruh pihak yang telah mendukung kelancaran penelitian ini yaitu Kemenkes yang telah memberikan bantuan dana hibah penelitian mahasiswa yang menunjang 1000 HPK, Ibu Kader Posyandu Anggrek yang telah memberikan bantuan dalam pencarian panelis penelitian kami, Pihak Bakesbangpol dan Dinas Kesehatan Kota Surabaya yang telah memberikan ijin, dan tidak lupa kepada dosen pembimbing yang telah memberikan bimbingan dan pengajaran kepada penulis.

\section{DAFTAR PUSTAKA}

Brown, J. E. (2011) Nutrition Through The Life Cycle. 4th edn, Cengage Learning. 4th edn. USA: Cengange Learning. doi: 10.1111/j.1753-4887.2004.tb00011.x.

Diniyyah, S. R. and Nindya, T. S. (2017) 'Asupan Energi, Protein dan Lemak dengan Kejadian Gizi Kurang pada Balita Usia 24-59 Bulan di Desa Suci , Gresik', Amerta Nutrition, 1(4), pp. 341-350. doi: 10.20473/amnt.v1.i4.2017.341-350.

Elastri, A. (2015) Pengaruh Substitusi Ekstrak Kulit Buah Naga Merah terhadap Kualitas Es Krim. Universitas Negeri Padang.

Fauziah, L., Rahman, N. and Hermiyanti (2017) 'Faktor Risiko Kejadian Gizi Kurang Pada Balita Usia 24 - 59 Bulan di Kelurahan Taipa Kota Palu', Jurnal Ilmiah Kedokteran, 4(3), pp. 27-35.

Kementerian Kesehatan Republik Indonesia (2013) Riset Kesehatan Dasar Tahun 2013.

Kurniawan, R. (2017) Pengolahan Koro Benguk (Mucuna pruriens), Oat (Avena sativa), Dan Apel Fuji (Malus sylvetris) Sebagai Bahan Snack Bar. Universitas Katolik Soegijapranata Semarang.

Kusumastuti, S. and Adriani, M. (2017) 'Pengaruh Substitusi Susu Kedelai dan Mocaf ( Modified Cassava Flour

) Terhadap Daya Terima , Kandungan Serat dan Nilai Ekonomi Produk Es Krim Naga Merah', Amerta Nutrition, 1(3), pp. 252-260. doi: 10.20473/amnt.v1.i3.2017.

Marwah (2018) Kualitas Fisikokimia Biskuit Pada Berbagai Komposisi Tepung Terigu, Tepung Dangke, dan Tepug Sagu. Universitas Hasanuddin.

Mufida, L., Widyaningsih, T. D. and Maligan, J. M. (2015) 'Prinsip Dasar Makanan Pendamping Air Susu Ibu 
(MP-ASI) untuk Bayi 6 - 24 Bulan: Kajian Pustaka', Jurnal Pangan dan Agroindustri, 3(4), pp. 16461651.

Mulyadi, A. F. et al. (2014) 'Karakteristik Organoleptik Produk Mie Kering Ubi Jalar Kuning (Ipomoea batatas) (Kajian Penambahan Telur Dan CMC)', Jurnal Teknologi Pertanian, 15(1), pp. 25-36.

Palupi, N., Zakariya, F. and Prangdimurti, E. (2007) Pengaruh Pengolahan terhadap Nilai Gizi Pangan. Bogor: Departemen Ilmu dan Teknologi Pangan-Fateta-IPB.

Rottie, J. V, Kundre, R. and Datesfordate, A. H. (2017) 'Hubungan Pemberian Makanan Pendamping Air Susu Ibu ( MP-ASI ) Dengan Status Gizi Bayi Pada Usia 6-12 Bulan Di Wilayah Kerja Puskesmas Bahu Manado', Journal Keperawatan, 5(2), pp. 1-7.

Sarastuti, M. and Yuwono, S. S. (2015) 'Pengaruh Pengovenan dan Pemanasan terhadap Sifat-Sifat Bumbu Rujak Cingur Instan selama Penyimpanan', Jurnal Pangan dan Agroindustri, 3(2), pp. 464-475.

Sarifudin, A. et al. (2015) 'Pengaruh Penambahan Telur Pada Kandungan Proksimat, Karakteristik Aktivitas Air Bebas ( A W ) Dan Tekstural Snack Bar Berbasis Pisang ( Musa paradisiaca )', Agritech, 35(1), pp. 1-8.

Savitri, D., Al-Baarri, A. N. and Abduh, S. B. M. (2014) 'Efek Pemanasan pada Susu Sapi Full Cream dengan Penambahan Gula Sukrosa, D-Fruktosa, dan D-Galaktosa terhadap Intensitas Warna dan Aroma', Jurnal Aplikasi Teknologi Pangan, 3(4), pp. 157-159.

Sundari, D., Almasyhuri and Lamid, A. (2015) 'Pengaruh Proses Pemasakan Komposisi Zat Gizi Bahan Pangan Sumber Protein', Media Litbangkes, 25(4), pp. 235-242.

Whitney, E. and Rolfes, S. R. (2008) Understanding Nutrition. 11th Editi. USA: ThomsonWadsworth.

Zwer, P. (2010) Oats : characteristics and quality requirements, Woodhead Publishing. Woodhead Publishing Limited. doi: 10.1533/978-1-84569-563-7.2.163. 